\title{
Who Is In the "We"? Interrogating the African Union's Agenda 2063 and Youth Political Participation
}

Job Shipululo Amupanda, University of Namibia, Windhoek, Namibia

\begin{abstract}
Most analyses of the African Union (AU) focus on the politics of the state and presidents. There are very few analyses that focus on aspects such as youth development. This article departs from that tradition. It argues that although the youth were always part of important historical developments in Africa, they have remained on the periphery. In recent times, particularly since the transformation of the Organization of African Unity into the AU in the 2000s, the youth development agenda has begun to receive attention at the policy level. In 2015, the AU through Agenda 2063 went a step further by elevating youth matters to the mainstream continental policy framework. While these developments are all welcome, it emerges clear that in the arena of youth political participation, the continent remains hesitant. Where the AU and its member states adopt the language and grammar of youth inclusion, of which youth political participation is often limited, such is not met with fitting institutional and practical policy arrangements. This article finds that the African elite is in for a rude awakening, as we have witnessed since 2011, given the discovery by the African youth of new methods of political participation in post-colonial Africa. It advocates for the adoption of the African community outlook to a youth state policy, argues for linking youth to the project of economic freedom, and implores the African elite to embark upon the decolonial project to resolve the bearings of coloniality of being, power and knowledge.
\end{abstract}

\section{Introduction}

Although the youth played an important role in the fight against colonialism in Africa, the liberating generation upon taking office did not see the need of placing youth development at the center of state policy in the liberated zones. The youth were to regard themselves as beneficiaries of an independent Africa which must be grateful to the fearless freedom fighters who freed the continent from colonial rule. 24 years after Namibia attained independence, former President of Namibia Hifikepunye Pohamba gave this warning to the youth of Namibia on 26 August 2014: "this [liberation struggle] was not easy as some of you want to believe. It was hard, long and bitter and we, the old freedom fighters, fought to the end and liberated the country and the people. Some of us lost our lives because of this right cause (Shivute, 2014).

In some extreme cases, the expectations of the youth to sing praises to liberating heroes led to dictatorships. In Malawi, President Kamuzu Banda ensured that everything in Malawi had been revolved around him. As Malawian academic Professor Wiseman Chijere Chirwa explains "throughout the 1960s, political songs reflected Banda's consolidation of power and his emerging dictatorship. Because of his heroic triumph, everything in the country belonged to him" (Chirwa 2001, p. 8). African liberation leaders even created concepts and philosophies that were forced 
down the throats of the citizens as national philosophies and concepts. South African political scientist Prince Mashele explains such an occurrence in Kenya:

In Kenya, during the reign of Daniel Arap Moi... citizens were obliged to follow in the footsteps of Moi. To entrench his despotism, Moi introduced a philosophy called Nyayo (footstep) projecting himself as a pathfinder and the rest of society as followers. Political commentators who dared not to follow in Moi's footsteps faced one of two hard realities: you disappear or flee to exile. So serious was Moi about his Nyayo philosophy that he could replace a vice-chancellor of any university with someone prepared to follow in the correct political footsteps. (Mashele, 2011)

The continent is, therefore, nourished with many examples illustrating how African liberation leaders perceived post-independent Africa as a personal trophy they obtained for liberating the continent through their heroic deeds. The citizens, particularly the youth, must at all time - it was made clear - be grateful and celebrate the freedom fighters and allow them to rule undisturbed. Fast forward to 2017, Africa still has the world's oldest leaders. Below is an illustration of Africa's top 20 oldest presidents for illustrative purposes;

Table 1

Rulers by country and age

\begin{tabular}{|lll}
\hline Name & Country & Age \\
\hline 1. Robert Mugabe & Zimbabwe & 93 \\
\hline 2. Beji Caid Essebsi & Tunisia & 91 \\
\hline 3. Paul Biya & Cameroon & 84 \\
\hline 4. Abselaziz Bouteflika & Algeria & 80 \\
\hline 5. Ellen Johnson Sirleaf & Liberia & 79 \\
\hline 6. Alpha Conde & Guinea & 79 \\
\hline 7. Peter Mutharika & Malawi & 77 \\
\hline 8. Hage Geingob & Namibia & 76 \\
\hline 9. Teodoro Obiang Mbasogo & Equatorial Guinea & 75 \\
10. Jose Eduardo dos Santos & Angola & 75 \\
11. Alassane Ouattara & Cote d'ivore & 75 \\
12. Jacob Zuma & South Africa & 75 \\
13. Mohammadu Buhari & Nigeria & 74 \\
14. Denis Ngueso & Congo & 74 \\
\hline 15. Akufo Addo & Ghana & 73 \\
16. Yoweri Museveni & Uganda & 73 \\
\hline 17. Pakalitha Mosilili & Lesotho & 73 \\
18. Omar al-Bashir & Sudan & 73 \\
\hline 19. Ibrahim Boubacar Keita & Mali & 72 \\
\hline 20. Ismail Omar Guelleh & Djibouti & 71 \\
\hline
\end{tabular}


To put Table 1 in fitting context and to understand how liberating leaders in Africa saw themselves as the only ones to govern Africa, it is necessary to juxtapose the above table to Table 2 of Africa's longest serving leaders. The table below shows that most of Africa's oldest leaders are also the longest serving leaders. Although it may appear obvious that the oldest would be longest serving, it must be clarified, for example, that while Ghana's Akufo Addo may be Africa's $15^{\text {th }}$ oldest leader, he only has been in office a few months, having assumed office only in January 2017. Namibia's Hage Geingob is Africa's $8^{\text {th }}$ oldest leader but has only spent two years in office since his inauguration in March 2015.

Table 2

Leaders by country and years in office

\begin{tabular}{cll}
\hline Name & Country & Years in office \\
\hline 1. Paul Biya & Cameroon & 42 years \\
2. Teodoro Obiang Mbasogo & Equatoria Guinea & 38 years \\
3. Jose Eduardo dos Santos & Angola & 38 years \\
4. Robert Mugabe & Zimbabwe & 37 years \\
5. Yoweri Museveni & Uganda & 31 years \\
6. Omar al-Bashir & Sudan & 28 years \\
7. Idris Deby & Chad & 27 years \\
8. Isaias Afwerki & Eritrea & 26 years \\
9. Paul Kagame & Rwanda & 23 years \\
10. Denis Sassou Nguesso & Congo & 20 years \\
\hline
\end{tabular}

This state of African leadership has not only generated an interest by foreign scholars, such as Aguilar (1998), but from countries led by relatively younger leaders. African scholars and researchers have also taken keen interest in this debate. This debate is captured around the concept of gerontocracy. Nigerian academic, Omotade Adegbindin, explains that a gerontocracy "is a political system, a form of oligarchical rule, whereby a small group of elderly individuals are in control of power. Unpopular due to its peculiar nature, it is in short, a rule by old men" (Adegbindin, 2011, p. 454). Drawing from other scholars to locate this concept in Africa, Adegbindin (2011) captures Dei (1994) explaining that in African tradition a gerontocracy is seen as occurring where "respect for the authority of elderly persons for their wisdom, knowledge of community affairs, and 'closeness' to the ancestors... there is in Africa a general belief that 'old age comes with wisdom and an understanding of the world"' (Adegbindin, 2011, p. 13). Kenyan academic Peter Onyango Onyoyo provides clarity in detail:

Gerontocracy is the rule by elders or a type of government that associates leadership with elders. ... Ipso facto in several African traditional societies in which customary law ruled the lives of people, the role of elders was substantial and critical for order and harmony. The elders are construed to be the custodians of customary law, its promulgators and 
enforcers... In the post-independent Africa, gerontocracy in the political sense has become notorious as some elders cling on power to dominate and favour their next of kin. Zimbabwean President Robert Mugabe is an example in which the leader sees his status as elder to be the reason to cling on power. The late Muammar Ghedafi did the same in Libya, President Paul Biye of Cameroon, and the late President Eyadema of Togo did the same. Elders in political leadership in Africa have been associated with hunger for power other than wisdom. (Onyoyo 2017, pp. 2-3)

It should, therefore, be no surprise that the entire structure of the OAU did not have a clear and specialized function dedicated to a continental youth development agenda. The Pan African Youth Movement (PYM) which later became the Pan African Youth Union (PYU) established in 1962 (a year before the founding of the OAU in 1963) was recognized by the OUA but never integrated into its activities. Historically, the PYM consisted of the youth of African ruling political parties in general and youth of former liberation movements in particular. After achieving independence, the PYM lost currency in the eyes of the liberating leaders subsequently losing momentum (Nueys, 2012). The African Union (AU), the successor of the OAU, established in 1999 , only became concerned with youth development seven years after its formation. This is confirmed by the AU 2011 State of the African Youth Report 2011 in no uncertain terms.

Africa's commitment to youth development and welfare was amply manifested in 2006 with the adoption by African Heads of State and Government of the African Youth Charter. The charter provides a framework for developing and implementing more tangible youth policies and programmes. (AUC, 2012, p. VII)

In a foreword to the same report, Professor Jean-Pierre Ezin, the then Commissioner for Human Resources, Science and Technology of the African Union Commission (AUC), summarized what to him was continental commitment to the continental youth development agenda.

The African Union Commission has come a long way in its efforts to promote youth development and empowerment in Africa. It developed the African Youth Charter, which was approved by African Heads of State and Government in 2006 and which entered into force in a relatively short time. The Charter constitutes a continental legal framework that seeks to re-position the challenges, potential, contributions and rights of young people in the mainstream of Africa's socio-economic growth and development. In 2009, the AU Executive Council declared the years 2009-2018 as the Decade for Youth Development and Empowerment in Africa. Subsequently, the AU Ministers in Charge of Youth Affairs approved the Decade Plan of Action (DPoA) - a roadmap for accelerating the implementation of the charter. By deciding to focus on the theme Accelerating Youth Empowerment for Sustainable Development for the 2011 Summit of African Union Heads 
of State and Government, the AU demonstrates the importance it attaches to the role and contribution of the youth in the development process. (AU 2012, p. VI)

The mindset of the liberation leaders - of youth to be grateful to political freedom fighters - has extended to the technical staff of the AUC. How else does one explain AUC commissioner Ezin's conclusion that something as flimsy as a theme can be regarded as demonstrating the importance that the AU attaches to the role and contribution of the youth in the development process? In 2011, the United Nations Economic Commission for Africa (ECA) released its 2011 African Youth Report. Abdoulie Janneh, the then United Nations Under-Secretary-General and Executive Secretary of the Economic Commission for Africa, did not conceal the reality of the exclusion and nonparticipation of African youth in decision making.

As argued in this report, young people need an enabling environment politically, economically and socially to thrive in our countries. They need to be empowered so that they can be represented and participate in decision-making processes that affect their lives. Though Africa has made progress in providing education and skills for more young people than ever before, youth unemployment and underemployment remain a major challenge. Innovative approaches and in-depth analysis of youth issues at both the design and implementation phases of policies and programmes are needed to ensure effective delivery and better outcomes towards a great future for the young women and men of Africa. (Economic Commission for Africa, 2011, p. VIII)

To its credit, the AU distinguished itself from the OAU by creating a youth division within the structures of the AUC. According to the AU, the "youth division under the Department of Human Resources, Science \& Technology (HRST) is the division responsible for Africa's Youth Agenda in the African Union Commission (AUC)" (African Union Commission, 2017). Most importantly, the AU's language and articulation of the importance of the youth division is the most telling in the subsequent sentences, "It [Youth Division] promotes youth participation such as organizing youth forums and celebrating Africa Youth Day. By harmonizing and coordinating member states as well as bringing together all relevant stakeholders, the youth division is mandated to, among other functions, use the outcomes and recommendations from all sectors through appropriate training frameworks to strengthen the African Youth" (African Union Commission, 2017).

What the above states is simply that the AU sees youth participation as represented by flimsy things such as celebrating Youth Day. This mindset is similar to that of Kamuzu Banda of Malawi, as discussed earlier, who saw the role of the youth and women as that of singing, clapping hands and celebrating him. The AU makes it clear that the mandate of the division is not to ensure that youth have input into decisions but merely to receive and accept outcomes and recommendations. From the $21^{\text {st }}-25^{\text {th }}$ of May 2016, the AU held what was called the Banjul+10 Summit on the 10-year implementation of the African Youth Charter in The Gambia to review the 
progress made in regard to the African Youth Charter since its adoption in 2006. It was found that most African states still did not ratify the Charter. In the outcome document, the AU set a target of ensuring that there would be a "hundred percent ratification by the end of 2016" (African Union, 2016). Speaking on the future prospects for African youth, in Germany on 6 April 2017 at the Potsdam Dialogues, the AUC Commissioner for Human Resources, Science and Technology, Martial De-Paul Ikounga, disclosed that the wishful target of 100 percent ratification of the charter that was previously set in Banjul was not achieved (Ikounga, 2017).

What emerges clearly from the above is that to both the OAU and its successor the AU, the youth and the youth agenda are either a non-issue or peripheral issue. In response, the youth did not sit idle. There have been a number of responses from the African youth. Although the PYU enjoyed cordial relations with both the OUA and AU, it faced several challenges, particularly financial challenges, given the somewhat 'arm-chair' approach of leadership of the continental body. The continental youth body was forced to change its headquarters three times: from Conakry, Guinea, to Algiers, Algeria in 1967; then from Algiers to Khartoum, Sudan, in 2008 (NUEYS, 2012). Speaking at the African Youth Day on 1 November 2012, the former chairperson of the African Union Commission Nkosazana Dlamini-Zuma admitted the serious challenges faced by the PYU thus promising the AUC's commitment to embark upon the revitalization of the Pan African Youth Union (The Point, 2012). It does not require sophistication to note that revitalization can only take place when faced with decline and weakening.

From the $1^{\text {st }}$ to $4^{\text {th }}$ of November 2013 in Tunisia, the AUC in collaboration with the New Partnership for African Development (NEPAD) coordinating Agency, the African Development Bank and the ECA organized a youth consultative meeting on the envisaged Agenda 2063. This meeting culminated in the establishment of the AU Youth Working Group (AUYWG). The AUYWG later transformed itself into the African Youth Commission (AYC) that held its first General Assembly and elected the founding leadership in January 2017 on the sidelines of the AU Summit in Addis Ababa, Ethiopia. The AYC, seeing itself as the youth version of the AUC, set its objective as an organization where "all inspiring and capable young African leaders and African Diaspora can organize themselves, take up their responsibilities, strengthen cooperation among the youth and youth structures as a platform, speak up and promote youth voices in the context of Africa's development" (African Youth Commission, 2017). It further outlined its objectives as:

to organize all young people in Africa and Diaspora for the promotion of African unity and development through linkage of youth and youth structures and mobilization of resources (human, technical, technology and finance) to support the work of African youth, youth structures, Pan African Youth Union and Youth Division of the African Union Commission in their quest to effective service delivery and advocacy activities on the African Youth Charter, other AU legal instruments and youth projects at national, regional and continental levels for the advancement of Africa (African Youth Commission, 2017, p. 4). 
As it did with the PYU, the AU took an "arm-chair" approach to the AYC although it played an indirect role in its creation. Towards the AYC General Assembly in January 2017, the African Union Youth Division released a statement that was regarded as an attempt to either sabotage or distance the continental body from the youth program. The statement, released on 13 January 2017, merely a week before the youth General Assembly, read:

With regards to the upcoming AYC Annual General Assembly on the 22-25 January 2017 in Addis Ababa, we wish to categorically state that we have not been involved in the coordination of this event as has been erroneously reported across various media. Unfortunately, this avoidable situation is a misrepresentation that has caused confusion, particularly among prospective participants, and simultaneously hampered the event's credibility. (African Union Youth Division, 2017)

While making such damaging remarks, the division still went on to state that it would encourage "pro-active initiatives of African youth in forming organizations, networks or think tanks as a response to the prevailing challenges that affect them; whether it is at the national, regional or continental levels" (African Union Youth Division, 2017). Be that as it may, the AYC General Assembly went ahead and elected its leadership. This then meant that there were now two continental youth organizations: the PYU and the AYC. One of the arguments used by those at the forefront of AYC is that unlike PYU that is host to the National Youth Councils, the AYC membership is open to individual youth and civil society organizations that would not get an opportunity to engage in the continental youth development agenda under the PYU framework. The other argument used against the PYU is that it appears to be too political and aligned to ruling parties in Africa of which some are responsible for the suppression of the youth and underdevelopment. In other words, the PYU, through its national youth councils, stands complicit.

There have been responses from African youth, responses to gerontocracies, authoritarianism, corruption and underdevelopment, outside the PYU and AYC structures. One of the well-known initiatives taken by the youth of Africa to ensure political participation is what has come to be known as the Arab Springs - the popular grassroots protests that took place in North Africa and toppled several African dictators. Ruge (2012) explains what underpinned the Arab Spring.

At the heart of the Arab Spring was a disgruntled youth class seeking democratic representation and economic participation. Remember Mohamed Bouazizi, the Tunisian street vendor whose self-immolation launched the uprisings? He didn't set himself ablaze because he had a smart phone. His self-immolation was his last desperate attempt to bring attention to his economic exclusion. His peers in the region sympathized and, almost overnight, Tunisia and the political landscape of most of Northern Africa changed. It was a signal that Africa's ruling class was under siege. On one end, Mr. Bouazizi, aged 26, represented Africa's emerging youth class, an impatient demographic eager to upend the 
status quo (he was only five years younger than the median Tunisian). On the other, deposed dictator Ben Ali, age 76, stood as a breed of elder statesmen - disconnected from the needs of populations, and facing extinction.

As dictators in North Africa were being toppled, their contemporaries in the rest of the continent worked hard to control the youth and avoid similar uprising. Ugandan President Yoweri Museveni is said to have deployed the military into the streets of Kampala to quell protests (Smith, 2011). Despite these attempts, the youth in the zones with long serving and authoritarian leaders still managed to wage protests in one way or the other. Years later, in 2014, the long-serving despot Blaise Compaore of Burkina Faso was forced to flee the country. Pictures of youth jubilantly jumping on top of seats in Burkina Faso Parliament went viral on social media (Berman, 2014). In stable democracies, where corruption and underdevelopment were rampant, particularly in Southern Africa, the youth formed radical social movements agitating for transformation, social justice and equality. Consider the case of Namibia as explained by Namibian academic Phanuel Kaapama (2016, p. 32):

Namibia reached her Fanonian moment... a new generation has entered the country's social and political scene and has forcefully asked penetrating new questions. So, Namibia's 'Fanonian moment' has come in the form of the [Affirmative Repositioning] AR movement. Other issues that have come under the radar of AR's fervent political eye include the perceived/allege widespread nepotism and corruption among the political and economic elite... The AR movement has 'declared war' on what it calls the "general zombie tendency" and its politics of hand-clapping and singing for the satisfaction of politicians, by working towards liberating the youth by converting them into active citizens and upright activists.

In some parts of North Africa, the youth have taken serious risks such as attempting to cross rivers and oceans into Europe in search of economic opportunities and political stability. Consider the case that The Gambia reported, "for its size, Gambia is experiencing a disproportionate number of people leaving the country. Its population is just under 2 million, yet over the past two years, it has been ranked fourth and fifth in the International Organisation for Migration's league of the six main nationalities identified attempting to cross the Mediterranean from Libya to Italy" (Hunt, 2015). In North, East and West Africa some youth resolved to join armed military groups such as Boko Haram and others (Onuoha, 2014).

This account and survey of continental youth political participation and developmental agenda was necessary to buttress the point that the scope of analysis should not only concern itself with the center and the institutions within its reach but should also consider (a) the existence of a periphery, (b) an understanding of why the periphery exists, and (c) the interaction, if any, between the center and periphery. The fundamental question, therefore, remains - who is in? Who is included in the center-led conversation and who do they represent? Indeed, who is out and what 
do they feel and what are they going to and willing to do about it? It is only when these questions are answered that it can be determine how youth political participation can be improved.

\section{Agenda 2063 - Who Is The "We"?}

\section{The Essence of Agenda 2063}

Agenda 2063 is a program of the AU adopted by African Heads of State and Government who assembled in Addis Ababa, Ethiopia, at the $24^{\text {th }}$ Ordinary Session of the Assembly of the Union in January 2015. In that session outcome, the African Heads of State and Governments romanticized Agenda 2063 as

"[an] endogenous plan for transformation. It harnesses the continent's comparative advantages such as its people, history and cultures; its natural resources; its position and repositioning in the world to effect equitable and people-centered social, economic and technological transformation and the eradication of poverty. It seeks to fulfil our obligation to our children as an intergenerational compact, to develop Africa's human capital; build social assets, infrastructure and public goods; empower women and youth; promote lasting peace and security; build effective developmental states and participatory and accountable institutions of governance; [articulate] Africa's vision and roadmap for sequencing our sectoral and normative, national, regional and continental plans into a coherent whole; plus, be a call to action to all Africans and people of African descent, to take personal responsibility for the destiny of the continent and as the primary agents of change and transformation, and a commitment from citizens, leadership, governments and institutions at national, regional and continental levels to act, coordinate, and cooperate for the realization of this vision" (AU, 2015, p. 13).

And, as a policy framework that aims to provide a collective developmental path for Africa's development, Agenda 2063 is anchored on 7 pillars: (1) a prosperous Africa based on inclusive growth and sustainable development; (2) an integrated continent, politically united and based on the ideals of Pan-Africanism and the vision of Africa's Renaissance; (3) an Africa of good governance, democracy, respect for human rights, justice and the rule of law; (4) a peaceful and secure Africa; (5) an Africa with a strong cultural identity, common heritage, shared values and ethics; (6) an Africa whose development is people-driven, relying on the potential of African people, especially its women and youth, and caring for children; and (7) an Africa as a strong, united and influential global player and partner (AU, 2015).

\section{Youth Content in Agenda 2063}

While there might not be a specific aspiration that speaks to youth political participation, it is important to note that aspiration 6 speaks of an Africa whose development is people driven and relies on the potential of the African people, especially its youth. What Agenda 2063 does, despite tokenism analysis, is to depart from a longstanding tradition of the OAU and AU of

peripherising youth development. In fact, the OAU Charter, in both Article II (purposes) and 
Article III (principles), makes no mention or inference to youth (Elias, 1965). The Constitutive Act of the AU also does not change this state of affairs. Its Article 3 (on the Objectives of the AU) and Article 4 (on the Principles of the AU) both fail to make mention of the youth (AU, 2000). While some might argue that the youth do not necessarily warrant mentioning in these legislative instruments, it must be noted that the AU Constitutive Act mentions in Article 4 the promotion of gender equality (often a twin to youth empowerment/inclusion) as one of the principles of the AU. Agenda 2063, therefore, departs from the AU tradition of placing youth at the periphery. The policy framework admits that "no society can reach its full potential, unless it empowers ... youth" and sets an objective of having an engaged and empowered youth (AU, 2015). Furthermore, it articulates and makes the following daring declarations on youth as part of Aspiration 6:

- The youth of Africa shall be socially, economically and politically empowered through the full implementation of the African Youth Charter.

- All forms of systemic inequalities, exploitation, marginalization and discrimination of young people will be eliminated, and youth issues mainstreamed in all development agendas.

- Youth unemployment will be eliminated, and Africa's youth guaranteed full access to education, training, skills and technology, health services, jobs and economic opportunities, and recreational and cultural activities as well as financial means and all necessary resources to allow them to realize their full potential.

- Young African men and women will be the path breakers of the African knowledge society and will contribute significantly to innovation and entrepreneurship. The creativity, energy and innovation of Africa's youth shall be the driving force behind the continent's political, social, cultural and economic transformation.

It is evident that Agenda 2063 has some content on the youth. As stated before, the decision to place youth in a central/mainstream AU document is a serious departure from the policy positions and approach of both the OUA and AU. In 2013, the AU started consulting the youth regarding Agenda 2063. The consultations will later bear fruit if the content of Agenda 2063 is taken into consideration. In November 2013 in Hamamet, Tunisia, the AU held consultation with the youth on Agenda 2063. It was at this gathering that the youth immaculately presented to the AU their desire to actively participate in the politics and governance of the AU, and its member states. The youth went further to indicate that the Africa they want is one wherein they are involved in the drafting of policies and take an active part in the implementation and monitoring process. At that conference, youth political participation was invoked. Resultantly, a working group called the African Union Youth Working Group (AUYWG) was established to ensure that the resolution of the youth that gathered there was included in the African developmental way forward in general and in Agenda 2063 in particular. Four years later, in 2017, the AUYWG transformed itself into an independent continental youth organization, the AYC, whose primary purpose would be to monitor the AUC and the AU and ensure that youth concerns would not be placed at the periphery (Dhlamini, 2017). This development alone indicates not only the input youth made into Agenda 2063 but their determination to create their own independent spaces and ensure political 
participation. The other aspects of youth consultation and input into Agenda 2063 took place at the state level. The AU policy organ, at its July 2014 meeting in Equatorial Guinea, had tasked member states to embark upon domestic consultations with various stakeholders (youth, academia, women, civil society and women) and submit the outcomes to the AUC by 31 October 2014. South Africa, for example, held such consultation with the youth on 11 July 2014 (DIRCO, 2015).

\section{'It Is In But Not In'}

In November 2015, the biggest daily newspaper in Namibia, The Namibian, ran a story that President Hage Geingob had temporarily moved out of the State House to his mansion on the outskirts of the capital city, Windhoek, to allow for expensive renovations that were in line with his taste. The Presidential Affairs Minister, Frans Kapofi, was at pains in explaining as to whether the President had moved out of the State House. In response to journalists, who were asking for confirmation as to whether the president has indeed moved out, Kapofi flip-flopped stating the following, "He [president] is here but he is not here" (Immanuel \& Mongudhi, 2015). Kapofi's explanation is a fitting importation to explain youth political participation in Agenda 2063 or, though slightly amended, to 'it is in, but not in'. While there is considerable content and mention in Agenda 2063 of youth, it is not clear as to whether this constitutes political participation. The language and grammar of Agenda 2063 speaks to what the AU will do for youth and not what it can do together with youth. It sees youth as mere subjects to benefit from the generosity of their elders who have now mentioned them in their documents. It makes use of terms such as "support young people" and many 'othering' terms when discussing the youth. The main version, called the popular version of Agenda 2063, states the following as the actionable programs that speak to youth (AU, 2015):

... support young people as drivers of Africa's renaissance, through investment in their health, education and access to technology, opportunities and capital, and concerted strategies to combat youth unemployment and underemployment. Ensure faster movement on the harmonization of continental admissions, curricula, standards, programmes and qualifications and raising the standards of higher education to enhance the mobility of African youth and talent across the continent.

It is evident that what is an envisaged and actionable program of the Agenda 2063 does not include political participation. The language and grammar of Agenda 2063 make itself available to the interpretation that reform and youth inclusion are limited to health, education, technology, economic opportunities and education. Youth political participation is not conspicuously part of Agenda 2063. They are thus perceived as readily available beneficiaries of the political generosity of their elders who have now included their issues in key policy documents such as Agenda 2030. The youth are, therefore 'In but not in' in Agenda 2063. Agenda 2063 is often paraded, and its content so read, around the phrase of 'The Africa We Want.' Although it appears that youth are indeed part of the we, or they might perceive themselves as part of the we, it appears, on closer inspection, that the we is an exclusive imagery of the African Heads of State and Government. As 
will be further elaborated in the proceeding pages, youth political participation remains a peripheral concern despite making an appearance in key policy documents of the AU.

\section{African Political Elite Orientation towards Youth Political Participation}

As has been explored and displayed earlier, youth matters have always been peripheral in the imagination and discourse of African political leaders. If the youth matters are themselves peripheral, one can only imagine how distant youth political participation would be in the minds of African political leaders. To understand what and how African leaders perceive youth, one only needs to study how the African governments conceptualize ministries dealing with youth affairs. A short illustration is thus necessary.

Table 3

Country and youth participation

\begin{tabular}{ll}
\hline Country Name & Name of Ministry \\
\hline Angola & Youth and Sport \\
Burkina Faso & Youth, Professional Education and Employment \\
\hline Cameroon & Youth Affairs and Civic Education \\
DRC & Youth and Sports \\
Ethiopia & Youth and Sports \\
Gabon & Youth and Sports \\
\hline Kenya & Public Service, Youth and Gender Affairs \\
\hline Lesotho & Gender and Youth, Sports and Recreation \\
Liberia & Youth and Sports \\
Mali & Youth and Citizenship Building \\
Namibia & Youth, Sports and National Service \\
\hline Nigeria & Youth Development \\
Rwanda & Youth and ICT \\
\hline Senegal & Youth, Employment and Promotion of Civic Values \\
Sudan & Youth and Sports \\
The Gambia & Youth and Sports \\
Togo & Basic Development, Crafts, Youth and Youth Employment \\
\hline Tunisia & Youth, Sports, Women and Families \\
\hline Uganda & Youth and Children Affairs \\
\hline Zimbabwe & Youth, Indigenization and Economic Empowerment \\
\hline
\end{tabular}

Table 3 represents a random selection of 20 African countries and indicates the following: (a) most African leaders view the youth's main objective and role as that of entertainment, chasing footballs and dancing/singing during national events. It is for this reason that in most African countries youth ministries are placed together with recreation, sports, national service or civic education.; but (b) Zimbabwe sees youth in relation to economic empowerment and indigenization, 
Kenya links youth to planning, and Rwanda links youth to ICT which provides a new and fresh perspective that departs from the orthodox linkage of youth to entertainment and sports. With the exception of few cases, this illustrates that youth are perceived as peripheral issues. It is therefore understandable that youth play a very small, if any, role in continental agenda setting.

As such, it can be argued that despite its predecessor the OAU that started off as a peoplecentered continental body that at one point assisted non-state actors fighting for national liberation, the AU remains engaged in elite politics. It is therefore no surprise that, although Agenda 2063 speaks about fighting for the self-determination of the people of Western Sahara, the AU recently resolved to admit Morocco to the African Union without a clear explanation and direction (Kazeem, 2017). What is clear is that once an elite pact is concluded, the aspiration of young men and women fighting with determination in Western Sahara does not matter (Akwei, 2017). The youth, including those of Western Sahara, are to remain beneficiaries of the 'generous' elders who have mentioned them in key documents such as Agenda 2063. When the African passport was launched at the $27^{\text {th }}$ Summit of the AU in Kigali, Rwanda, the first recipients where not youth to symbolize a future-looking continent but the African elites, Rwandan President Paul Kagame and Chadian President Idris Deby Itno, who already enjoy diplomatic privileges until death. Giving these individuals African passports thus becomes irrelevant on close inspection (Adibe, 2016). These are amongst the many reasons that support the argument that the AU prioritizes elite interest dwarfing any elevation of matters such as youth political participation.

In a 2011 Afrobarometer's working paper titled The Political Participation of Africa's Youth: Turnout, Partisanship and Protest, Danielle Resnick and Daniela Casale capture the orientation of African youth as it relates to political participation:

Our findings suggest that Africa's youth, particularly those residing in urban areas, operate in broadly similar ways to their counterparts in other regions of the world. In comparison with their older compatriots, the youth vote less and are more likely to demonstrate no partisanship or an attachment to opposition parties rather than any affinity to incumbent parties. Yet, the likelihood of their involvement in protests is not significantly different from that of their older counterparts. Moreover, we find that the youth, unlike older voters, tend to vote less the longer an incumbent party has been in office. In addition, poor incumbent performance on job creation, compared with other socio-economic issues, increases the likelihood of the youth to express either no partisanship or an affinity to the opposition. In terms of protest activity, higher levels of education and economic deprivation, as well as a lack of satisfaction with democracy, increase the likelihood that the youth will protest while demonstrating a null impact on their older cohorts' protest activities. (Resnick \& Casale, 2011, p. 2)

At the time Resnick and Casale (2011) published their paper, Africa had just experienced the youth-led uprising in North Africa that toppled long-serving dictators and authoritarian leaders. As stated in the introduction to this paper, a young Mohamed Bouazizi found himself in circumstances that were confirmed by the studies of Resnick and Casale, which led him to setting 
himself alight and becoming a martyr of the youth-led revolution that spread fast and had as its casualty some long-serving African authoritarian leaders. The marginalization of the youth and the consequences thereto can be placed squarely at the doorstep of an unresponsive policy environment and the 'periphering' of the youth from mainstream political participation. Indeed, it is the failure of African states to engage the youth into activities that are aimed at influencing the selection, constituting and general decisions of the government bureaucracy. As previously stated, the marginalization of the youth from mainstream political participation and 'periphering' the youth did not leave the youth idling. They found alternative forms of political participation at their location - the periphery. To the surprise of many, as what happened with the Arab Spring and with popular urbanized protests in southern Africa, the periphery found its way to the mainstream forcing the political elite to either capitulate or engage those who were seen as 'peripherised' (Branch \& Mampilly, 2015).

The AU in Agenda 2063 adopted a language and grammar that can be said to have diagnosed the danger of 'peripherising' the youth. In what can be seen as either appeasement or commitment to prevent the relapse of the popular protests, Agenda 2063 promised that "all forms of systemic inequalities, exploitation, marginalization and discrimination of young people will be eliminated, and youth issues mainstreamed in all development agendas" (AUC, 2015). Although the AU documents, such as Agenda 2063, appear to suggest that the AU and its member states are somewhat committed to bring about real political participation, its rhetoric does not seem to be supported by credible institutional arrangements. Consider the Youth Division of the AU that is responsible for Africa's youth agenda at the AUC. The division explains that it promotes youth participation by "organizing forums and celebrating Africa Youth Day" (AU, 2017). It goes further to admit that its mandate is to use the outcomes and recommendations to strengthen the youth. This is a clear indication of two things: firstly, like is the case amongst AU member states, the AU understands the youth in the context of entertainment and celebration days like Africa Youth Day; secondly, it is an admission that the mandate of the division is not to influence decisions but to use the outcomes and recommendation (already made) to strengthen the youth. In other words, youth are to be beneficiaries and recipients of the "generosity" of the elders. Had the AUC, its youth division and member states been interested in genuine political participation, it would have endorsed campaigns such as Not Too Young to Run, supported and spearheaded by the UN Secretary-General's Envoy on Youth, Ahmad Alhendawi. This campaign aims at doing away with restrictive practices, particularly in most African countries, where state policy prevents young people from running for public office (Srour, 2016)

\section{Conclusion - What Is To Be Done?}

\section{Make the Circle Bigger}

If there is any lesson to be learned from recent popular and far-reaching events spearheaded by the youth from the Arab Spring in North Africa to violent extremists in West and East Africa and popular urbanized protests in southern Africa, it is this: it is in the interest of the African elites 
to engage the African youth and ensure that they facilitate political participation in mainstream national politics in a genuine, inclusive and constructive manner. The African youth have proven that they do not need permission and are capable of organizing their own independent forms of political participation that often lead to their desired outcomes - destructive as it may seem particularly to those profiting in an exclusive status quo. It is in the interest of peaceful coexistence for the African leaders to create an enabling environment for political participation of youth. The current leaders must, indeed, make the circle bigger.

\section{Linking Youth to Economic Freedom}

The underlying objective of the African liberation struggle against colonialism was not only to bring about self-determination but also to solve the then contractions of political power. The understanding and imagination of the liberating leaders, such as the likes of Kwame Nkrumah, were that political freedom will lead to economic freedom for the oppressed masses on the African continent. In fact, one of Nkrumah's famous phrases has been one that states that you first seek the political kingdom and the rest shall be added unto you. The 'rest' that Nkrumah was referring to is seen as the economic kingdom. It is now a common understanding that Nkrumah's dream was not fulfilled (Mashele \& Qobo, 2014). This dismal failure has not left youth idling. The youth have understood the liberating generation as having failed economically thus necessitating the current need for economic freedom fighters to emerge and fight for economic freedom (Shivambu, 2014). Although the youth understands that their mission is to continue the incomplete struggle to solve the remaining contradictions of economic power, the struggle was started by the liberating generation, and it has become impossible to pursue this struggle without confronting the very same fighters and victors of political freedom because of their positionality (Seibeb, 2016). For as long as the AU member states continue to define youth from the perspective of entertainment, sports and agents of celebration during national festivals and events, conflicts between these states and the youth will continue to occur. As such, examples of Zimbabwe, Rwanda and Kenya who locate youth in the context of economic freedom - viewing youth as an agency of solving the remaining contradictions of economic power - must be emulated.

\section{Appropriate African Community Outlook to Youth State Policy}

Because of the conduct of the politics of the state, the liberation generation has often taken an opportunistic approach to the appropriation of African tradition and culture. The African political elites often resort to African tradition and practices such as respect of elders to opportunistically escape from accountability and evade serious questions related to their political conduct. There are several African practices and value systems that remain important and can assist in bringing about the youth's political participation in the mainstream national discourse. One such African value system is the African outlook or conceptualization of a community. Africans have always understood the community as consisting of (a) the dead, (b) the living, and (c) those yet to be born (Kamalu, 2000). The dead are regarded as part of the community although may not be visible to everyone. They are in the ancestry watching over, supervising and protecting the living. 
For their part, the living plays a dual role: firstly, they live their lives and lead society in adherence in regard and observation of the values and norms that were left by the departed who are in the ancestry and part of the community watching over them; secondly, the living leads their lives and society in such a way that they preserve a good community for those who have yet to arrive on earth. The community must be preserved in such a way that when the living takes their position in the ancestry, they will be watching over the new living (the present unborn) who will preside over a community that they left in good shape. The African elites opportunistically leave out this outlook that has ensured accountability and self-regulation in the African traditional society (Sesanti, 2011). An individual with this outlook would be hesitant of stealing the collective resources for personal use because he/she is cognizant of the ancestors who are watching his deeds, even those committed behind closed doors. He/She would be bothered by the thought of one-day sitting in the ancestry witnessing the living scavenging and suffering because he/she looted and squandered collective resources. Said differently and in the context of political participation, the African political elite should ensure political participation of the young, fearing an eye-sore when they are in the ancestry because they have left the unexposed and inexperienced to take over state power without the requisite experiences because they were not given an opportunity to learn and practice when they were young.

\section{Decoloniality - Reimagining Africa}

Related to the above discussion is the question of decoloniality, one of the many failures of the liberating generation. The common mistake that the African elite have made over the past decades of political freedom is to think that it is only them who are concerned about the African perspective and the fight against colonialism. They have concluded that the generation of youth born after independence has been influenced by western values. The African elites always see the demands by this generation of youth as sponsored from outside, and thus concluded that the growing dissent is the artwork of the underground of a 'third force.' The youth of southern Africa, through popular radical protests against inequality, poverty, underdevelopment and neoliberalism, have taken the African elites by surprise once it occurred that the discontentment is homegrown and, in some instances, has strong Pan Africa, Black Consciousness and African communalistic values (Mabhena, 2016). The demands on the state through radical protest actions for decent and dignified housing for all and the demands for free quality decolonized higher education are all

prevalent in southern African as a case in point. The state and African elites must seriously consider taking the decolonial discourse serious, and this includes dealing with the questions of coloniality of power, coloniality of knowledge and coloniality of being. All these questions raised by the youth of Africa speak to the deficit of their political participation.

\section{References}

Adegbindin, O. (2011). The problem of gerontocracy in Africa: The Yorùbá perspective as illustrated in the Ifá corpus. Human Affairs, 21, 454-469. 
African Union. (2016, May). 10 years of implementation of the African Youth Charter: Accelerating youth development in Africa. Banjul, Islamic Republic of Gambia: AU.

African Union Commission. (2015). Agenda 2063: The African we want. Retrieved from http://www.un.org/en/africa/osaa/pdf/au/agenda2063.pdf.

African Union Commission (AUC). (n.d.). Youth and the AUC. Retrieved from https://www.africa-youth.org/about-us/the-youth-division/youth-and-the-auc/.

African Youth Commission. (2017, January 13). Statement of clarification - AYC annual general assembly. Retrieved from https://www.africa-youth.org/statement-clarification-aycannual-general-assembly/.

Aguilar, M. I., Ed. (1998). The Politics of Age and Gerontocracy in Africa: Ethnographies of the Past \& Memories of the Present $1^{\text {st }}$ Edition. Trenton: Africa World Press.

Akwei, I. (2017, Jnuary 30). African, world leaders converge in Ethiopia for 28th AU summit. African News. Retrieved from http://www.africanews.com/2017/01/28/african-worldleaders-converge-in-ethiopia-for-28th-au-summit/.

African Union (AU). (2000, July 11). The Constitutive Act of the African Union. Retrieved from https://www.au.int/web/sites/default/files/pages/32020-file-constitutiveact_en.pdf.

Berman, R. (2014, October 31). A coup in Burkina Faso. Atlantic Newspaper. Retrieved from https://www.theatlantic.com/international/archive/2014/10/a-coup-in-burkinafaso/382192/.

Branch, A., \& Mampilly, Z. C. (2015). Africa uprising: Popular protest and political change. London: Zed Books Ltd.

Chirwa, W. C. (2001). Dancing towards dictatorship: political songs and popular culture in Malawi. Nordic Journal of African Studies, 10(1), 1-27.

Dei, G. J. S. (1994). Afrocentricity: A cornerstone of pedagogy. Anthropology \& Education Quarterly, 25(1), 3-28.

Dhlamini, P. H. (2017). From internet community to one governed by a constitution. Retrieved from http://www.ityafrica.net/2017/02/the-african-youth-commission-profile.html.

Economic Commission for Africa. (2011). African Youth Report 2011. Addis Ababa: United Nations Economic Commission for Africa.

Elias, T. O. (1965). The Charter of the Organization of African Unity. The American Journal of International Law, 59(2), 243-267.

Hunt, Louise. (2015, September 11). The Gambia faces battle to deter its young people from migrating abroad. The Guardian Newspaper. Retrieved from https://www.theguardian. com/global-development/2015/sep/11/the-gambia-migration-livelihood-empowermentagricultural-project-concern-universal.

Ikounga, M. D. (2017, April 6). Define a youth policy at international and regional level (speech). Potsdam Spring Dialogues 2017. Retrieved from https://www.sef-bonn.org/en/ events/potsdam-spring-dialogues/potsdam-2017/conference-report-speechesinterviews.html. 
Immanuel, S., \& Mongudhi, T. (2015, November 25). He is here but he is not here. The Namibian Newspaper. Retrieved from http://www.namibian.com.na/index.php?page $=$ archiveread\&id $=144722$.

Kaapama, P. (2016). Youth political retreatism, activism and militancy in Post-Colonial Namibia. In P. Bruhns' (Ed.) Youth matters: 10 years of the youth leadership development programme (YLDP) in Namibia. Pp. 30-36. Bonn, Germany: Friedrich-Ebert-Stiftung.

Kamalu, C. (2000). Foundations of African thought: A worldview grounded in the African heritage of religion, philosophy, science, and art. Trenton, NJ: Red Sea Press, 2000.

Kazeem, Y. (2017, January 31). Morocco has rejoined the African Union after a 33-year absence. Retrieved from https://qz.com/898645/morocco-has-rejoined-the-african-union-but-thewestern-sahara-question-remains/.

Mabhena, C. Z. (2016, December 11). Decoloniality in Africa. The Sunday News. Retrieved from http://www.sundaynews.co.zw/decoloniality-in-africa/.

Mashele, P. (2011). The death of our society. Pretoria: CPR Press.

Mashele, P., \& Qobo, M. (2014). The Fall of the ANC: What Next? Johannesburg, South Africa: Picador Africa.

NUEYS Admin. (2012, April 23). Pan African Youth Union (PYU). Retrieved from http://www.nueys.org/index.php?option=com_content\&view=article\&id=142:panafrican-youth-union-pyu\&catid=52:nueys-networks \&Itemid=75.

Onuoha, F. C. (2014, June). Why do youth join Boko Haram? United States Institute of Peace. Retrieved from https://www.usip.org/sites/default/files/SR348-Why_do_Youth_Join_ Boko_Haram.pdf.

Onyoyo, P. O. (2017). A theory of gerontocracy in the African customary law. Academia.edu. 2017. Retrieved from https://www.academia.edu/9644458/A_Theory_of_Gerontocracy_ in_the_African_Customary_Law?auto=download.

Resnick, D., \& Casale, D. (2011, November). Political participation of Africa's youth: Turnout, partisanship and protest [Afrobarometer Work Paper 136]. Retrieved from http://afrobarometer.org/publications/political-participation-africa\%E2\%80\%99s-youthturnout-partisanship-and-protest.

Ruge, TMS. (2012, October 29). African's gerontocracy isn't going to last much longer. The Globe and Mail. Retrieved from http://www.theglobeandmail.com/opinion/africas-gerontocracyisnt-going-to-last-much-longer/article4718552/.

Seibeb, H. H. (2016, June 1). Fanon and the positionality of Amupanda, Ngurare and Swartbooi [blog]. Retrieved from https://www.newera.com.na/2016/06/17/fanon-positionalityamupanda-ngurare-swartbooi/ (accessed May 20, 2017).

Sesanti, S. (2011). On African culture and politics: Reflections of a black journalist. Cape Town, South Africa: The Centre for Advanced Studies of a African Society (CASAS).

Shivambu, F. (Ed.). (2014). The coming revolution: Julius Malema and the fight for economic freedom. Auckland Park, South Africa: Jacana Media (Pty) Lmt. 
Shivute, O. (2014, April 23). Pohamba unveils statues at Omugulugwombashe. Retrieved from http://www.namibian.com.na/print.php?id=123592\&type $=2$.

Smith, D. (2011, April 29). Uganda unrest gathers pace despite bloody government crackdown The Guardian Newspaper. Retrieved from https://www.theguardian.com/world/ 2011/apr/29/ uganda-rebellion-crackdown-besigye-museveni.

Srour, R. (2016, November 22). Not too young to run. Retrieved from http://www.un.org/ youthenvoy/ 2016/11/launching-global-campaign-promoting-rights-young-people-runpublic-office/. 